\title{
LACK OF RELATIONSHIP BETWEEN APHID VIRUS VECTOR ACTIVITY AND POTATO LEAF ROLL VIRUS INCIDENCE
}

\author{
D.A.J. TEULON and M.A.W. STUFKENS \\ New Zealand Institute for Crop \& Food Research Limited \\ Private Bag 4704, Christchurch \\ Corresponding author: teulond@crop.cri.nz
}

\begin{abstract}
The relationship between activity of aphid virus vectors and incidence of potato leaf roll virus (PLRV) in seed potato crops was investigated using historical data. Numbers of PRLV aphid vectors (mainly green peach aphids) caught in a $7.5 \mathrm{~m}$ suction trap at Lincoln, Canterbury, and the incidence of primary and secondary PLRV for Ilam Hardy seed crops from the $\mathrm{PT}^{\circledR}$ seed potato certification scheme in Canterbury, were collated from 1982 to 2000. The degree of simple linear relatedness between aphid flight activity and virus incidence was examined. Climate variables, which may have contributed to aphid survival, reproduction and movement in potato crops, were also investigated. Very low correlation coefficients between all variables tested were obtained. Explanations for the lack of any relationship between potato aphid virus vector flights and virus incidence in potatoes are discussed.
\end{abstract}

Keywords: green peach aphid, potato leaf roll virus, forecast, aphid flight activity.

\section{INTRODUCTION}

Aphids are important pests of potato crops in New Zealand. They cause significant yield reductions through direct feeding and the transmission of about seven viruses (J. Fletcher, pers. comm.). The potato leaf roll virus (PLRV), which is exclusively transmitted by aphids (Robert et al. 2000), has been of particular concern in New Zealand because of increasing incidence in recent years (Fletcher 1997; Wright 1997).

Nine aphid species in New Zealand are capable of transmitting PLRV, including the green peach aphid (Myzus persicae (Sulzer)) which has historically been considered the most important aphid pest on potatoes in New Zealand and elsewhere. It is the most common species found on potatoes (Stufkens \& Teulon 2001) and is the most efficient vector of PLRV (Salazar 1996). It has also developed resistance to a number of insecticides in New Zealand (Cameron \& Walker 1988). This aphid has two strategies for surviving the winter: (1) as eggs in diapause on Prunus trees and (2) as active stages on many other host plants, such as brassica crops and weeds including volunteer potatoes. It migrates to potatoes in the spring where both winged and wingless aphids can spread virus into and throughout the crop. The main sources of infection for PLRV in New Zealand appear to be volunteer potatoes and secondary tuber-borne infection (J. Fletcher, pers. comm.).

Two other highly polyphagous species, the foxglove aphid (Aulacorthum solani) and the potato aphid (Macrosiphum euphorbiae), are found on potato crops in New Zealand in moderate numbers (Stufkens \& Teulon 2001) and are also vectors of PLRV. Like the green peach aphid they form colonies after alighting on crops. Other aphid species are found on potato crops infrequently but there is particular concern over the future impact of the melon aphid (Aphis gossypii) (a vector of several other potato viruses but not PLRV) in New Zealand (see Stufkens \& Teulon 2001).

In most parts of New Zealand peak aphid flights occur in late-spring and autumn with little flight activity in mid-winter and mid-summer (Lowe 1968; Till 1971; Miln

New Zealand Plant Protection 54:229-234 (2001) 
1978). In Canterbury, late spring flights coincide with the main period of potato planting and emergence and autumn flights overlap with the end of the main potato harvest (Stufkens et al. 2000). However, data from 16 years of trapping in Canterbury indicate that late-spring and autumn flight peaks of the three main PLRV vectors (predominantly green peach aphid) vary considerably between seasons and between years in their timing, magnitude and duration (Stufkens et al. 2000).

Numerous reports indicate the importance of winged aphids in the spread of virus in potatoes (Broadbent 1950; Hille Ris Lambers 1972; Bacon et al. 1976; Thomas 1983, 1997; Robert et al. 2000). Aphid flight activity is measured in several countries, including the Netherlands (Teulon 2001) and Scotland (Pickup \& Brewer 1994), to help indicate the need for aphid control.

Stufkens et al. (2000) pointed out that up-to-date information on aphid flights could be valuable to growers for use in aphid/virus pest management in Canterbury with potential benefits including increased potato yields and reduced control costs. They recommended the development of an aphid monitoring and virus forecasting programme to provide growers, especially potato seed growers in Canterbury, with timely information on aphid flights and potential virus risk. This paper details work to clarify the relationship between aphid activity, especially flight activity, and virus incidence in Canterbury.

\section{Aphid flights}

\section{MATERIALS AND METHODS}

Aphid flight activity was monitored at $7.5 \mathrm{~m}$ above ground with a suction trap at Lincoln, Canterbury, from July 1982 to June 2000 . Weekly aphid flight activity for the three main PLRV vectors, the green peach aphid, the foxglove aphid and the potato aphid, were collated for this period (Stufkens et al. 2000).

Virus surveys

Visual field surveys for primary and secondary PLRV on the foliage of seed potato crops have been undertaken since the early 1980s in New Zealand as part of various certified pathogen-tested seed potato schemes (Martin 1985). Primary virus results from infection in the 'current season', whereas secondary virus results from infection in the 'previous season', and both have different visual symptoms. Records from the virus survey from 1982 to 2000 were obtained from the New Zealand Seed Potato Certification Authority. Primary and secondary PLRV incidence, in terms of total number of potato fields with virus (at least one plant) and the mean number of virus-infected plants per hectare, were determined from these records for Ilam Hardy seed crops for the $\mathrm{PT}^{\circledR}$ seed potato certification scheme (Basic, $1^{\text {st }}$ generation and $2^{\text {nd }}$ generation) in Canterbury. The Ilam Hardy cultivar was chosen as it was grown in sufficient quantity throughout the sampling period.

Examination of data

Several correlations were calculated to measure the degree of relatedness between aphid flight activity and virus incidence, and between some climate variables which may have contributed to aphid survival, reproduction and movement and virus incidence (Table 1). Relationships were also examined graphically.

\section{RESULTS AND DISCUSSION}

The flight patterns of the three main PLRV aphid vectors (combined but mostly green peach aphids) from 1981-82 to 1998-99 were illustrated in Stufkens et al. (2000). They show considerable variation in late-spring and autumn flight peaks in terms of their timing, magnitude and duration between seasons and years.

The number of fields with at least one infected plant (Fig. 1a) and the mean number of virus-infected plants per hectare (Fig. 1b) for primary and secondary PLRV in Ilam Hardy seed crops for the $\mathrm{PT}^{\circledR}$ seed potato certification scheme (Basic, $1^{\text {st }}$ generation and $2^{\text {nd }}$ generation) in Canterbury from the 1982-83 to 1999-2000 seasons are illustrated. In 1982-83 and 1983-84, levels of secondary virus were very high, presumably reflecting high virus levels at the beginning of the $\mathrm{PT}^{\circledR}$ certification scheme. These years were not 

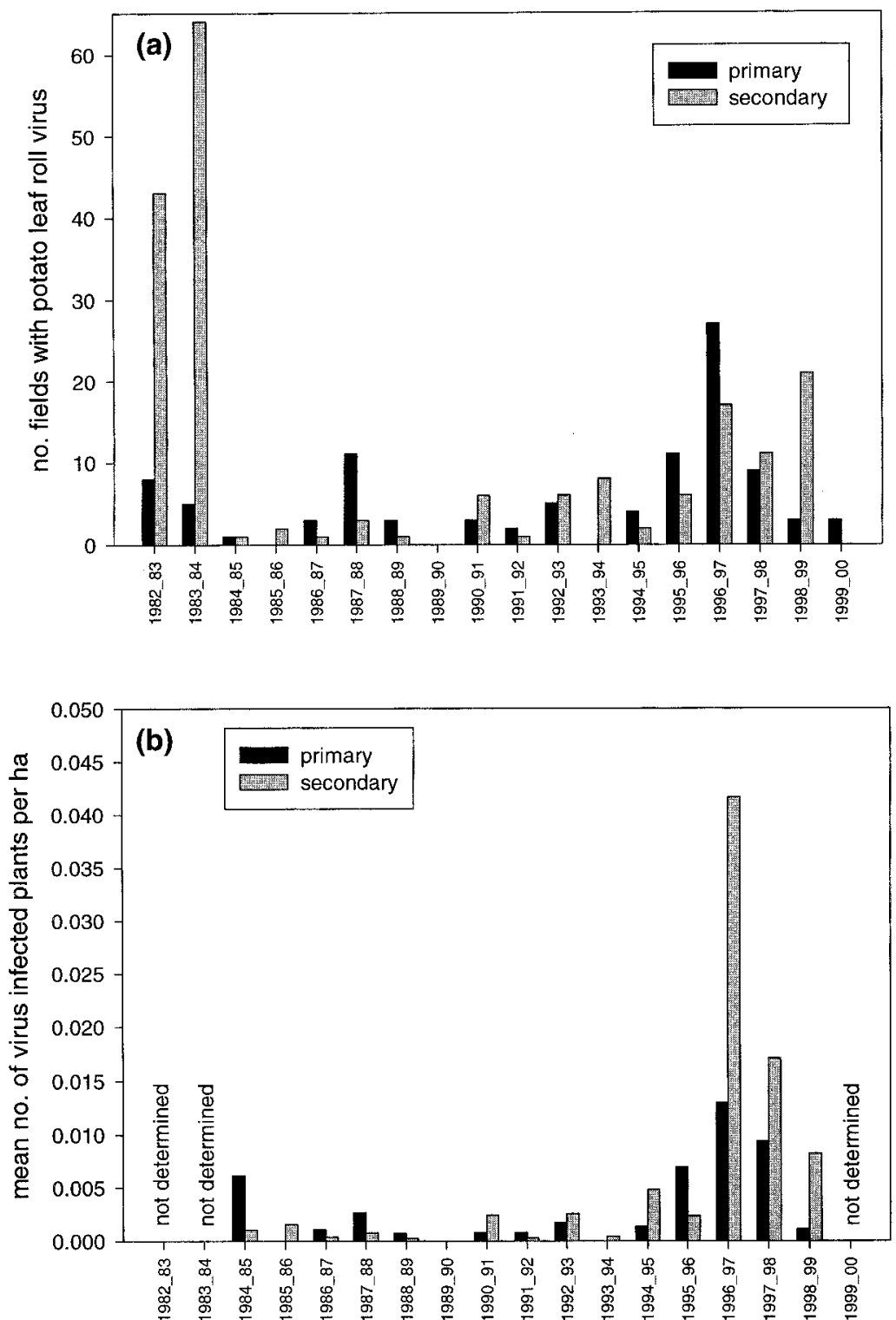

FIGURE 1: Primary and secondary potato leaf roll virus in Canterbury, 19822000. (a) Number of fields with at least one plant exhibiting virus symptoms. (b) Mean number of virus infected plants per hectare. 
included in subsequent examinations. For other years, PLRV incidence remained at relatively low levels, with a recent increase in virus incidence from 1995-96 to 1998-99.

The correlation coefficients indicating the degree of linear relatedness between aphid flight activity and virus incidence, and several climate variables that influence aphid activity and virus incidence, are listed in Table 1 along with the variables tested and the basis (premise) for their selection. For these results 'aphid' is used to refer to the three aphid PLRV vectors (listed above) and 'flight' includes the total number of these aphids caught during the time indicated. The temperature threshold of $4.3^{\circ} \mathrm{C}$ was used for degree day summation (van Emden et al. 1969).

TABLE 1: The degree of linear relatedness between aphid flight activity and virus incidence, and climate variables that influence aphid activity and virus incidence indicated by the correlation coefficient $(r)$.

\begin{tabular}{cccc}
\hline Correlation & Variable 1 & Variable 2 & $\mathrm{r}$ \\
\hline \multirow{2}{*}{ Premise: } & Large numbers of aphids increase the amount of $1^{\circ}$ virus in potato crops \\
in the same year. \\
1 & Total spring aphid flight & $1^{\circ}$ PLRV incidence (same year) & -0.18 \\
2 & Oct. to Mar. aphid flight & $1^{\circ}$ PLRV incidence (same year) & -0.07 \\
3 & Dec. to Mar. aphid flight & $1^{\circ}$ PLRV incidence (same year) & -0.12 \\
\hline
\end{tabular}

Premise: Large numbers of aphids increase the amount of virus in a potato crop, but the virus only becomes apparent in the following year.

$4 \quad$ Total spring aphid flight $\quad 2^{\circ}$ PLRV incidence (following year) -0.01

5 Oct. to Mar. aphid flight $\quad 2^{\circ}$ PLRV incidence (following year) -0.12

6 Dec. to Mar. aphid flight $2^{\circ}$ PLRV incidence (following year) -0.04

Premise: Virus is introduced into the crop by aphids late in the season, but virus only becomes apparent in the following season.

$7 \quad$ Total autumn aphid flight $\quad 2^{\circ}$ PLRV incidence (following year) $\quad-0.09$

8 Total autumn aphid flight $1^{\circ}$ PLRV incidence (following year) -0.33

Premise: Cold winter temperatures kill aphids overwintering on weeds, but not on trees, so that spring flights consist mostly of non-virus transmitting aphids.

$9 \quad$ Winter mean min. temp. $\quad 1^{\circ}$ PLRV incidence (same year) $\quad 0.07$ 10 Winter grass min. temp. $\quad 1^{\circ}$ PLRV incidence (same year) 0.01

Pemise: A warm spring encourages reproduction and movement of aphids within the crop, increasing the spread of $1^{\circ}$ virus (same year) or $2^{\circ}$ virus (following year).

11 DD from Sep. to Dec. $\quad 1^{\circ}$ PLRV incidence (same year) 0.18

12 DD from Sep. to Mar. $\quad 1^{\circ}$ PLRV incidence (same year) 0.12

13 DD from Sep. to Mar. $\quad 2^{\circ}$ PLRV incidence (following year) -0.04

All correlation coefficients were less than \pm 0.33 , which is below a level indicating a linear relationship of any strength. Furthermore, there was no evidence of non-linear correlation from visual observation of plotted points (D.A.J. Teulon, unpubl. data). Therefore, we were unable to find any simple relationship between flights of PLRV aphid vectors and PLRV incidence or between climate conditions that may have contributed to the incidence of virus transmitted by aphids.

There may be several explanations for the lack of any simple relationship between aphid activity and virus incidence. Firstly, the relationship between aphid vectors and 
PLRV incidence may be more complex than those tested above. Although the relationship between aphids flights and virus incidence in potatoes is recognized in the literature (Broadbent 1950; Hille Ris Lambers 1972; Bacon et al. 1976; Thomas 1983, 1997; Robert et al. 2000), more complex models like those developed by Nemecek et al. (1995) and Sigvald (1998) may be needed. Factors such as the source of aphid immigrants (e.g. from weeds with virus or trees without virus), and the relative importance of winged and wingless forms in virus spread, may need to be included. Another reason for the lack of a relationship between aphid activity and virus incidence is that the relationship between aphid vectors and PLRV incidence may have been masked by pest management activities. This may include the amount and type of insecticide used for aphid control in different years, the timing of autumn crop burn-off in different years, and/or the degree of aphid infestation on crop regrowth after burn-off. All could contribute to different levels of virus irrespective of aphid flights. It is also possible that there is no relationship between aphid flight and PLRV incidence. However, this seems unlikely in light of published evidence to the contrary.

Despite the lack of any obvious relation between aphid flight activity and virus incidence, members of the potato industry overseeing this research in Canterbury reported that the weekly provision of aphid flight activity information was very well received by potato growers and was used an indication of virus risk for their pest management programmes.

\section{ACKNOWLEDGEMENTS}

We thank the NZ Seed Certification Authority (Harold Maunder, Ron Gall) and AgriQuality (Evan Johnstone) for access to the virus records, and Ruth Butler (Crop \& Food Research) for statistical advice. This work was funded in part by the Potato Industry Research Development Grants Committee of the NZ Vegetable and Potato Grower's Federation, AB Annand Ltd, Alex McDonald Merchants Ltd, Dawe's Produce Ltd, Eurogrow Potatoes, McCains Foods Ltd, Robinson RG Produce Ltd and Technology NZ.

\section{REFERENCES}

Bacon, O.G.; Burton, V.E.; McLean, D.L.; James, R.H.; Riley, W.D.; Baghott, K.G.; Kinsey, M.G. 1976: Control of the green peach aphid and its effects on the incidence of potato leaf roll virus. J. Econ. Entomol. 69: 410-414.

Broadbent, L. 1950: The correlation of aphid numbers with the spread of leaf roll and rugose mosaic in potato crops. Ann. Appl. Biol. 37: 58-65.

Cameron, P.J.; Walker, G.P. 1988: Insecticide resistance in green peach aphid from potatoes in South Auckland. Proc. 41 st N.Z. Weed and Pest Control Conf.: 85-89.

Fletcher, J. 1997: Management of potato viruses. Commercial Grower 52(10): 33-5.

Hille Ris Lambers, D. 1972: Aphids: their life cycles and their role as virus vectors. Chapter 3. In: de Bokx, J.A. ed. Viruses of potatoes and seed-potato production. Wageningen, Pudoc. Pp. 37-56.

Lowe, A.D. 1968: Alate aphids trapped over 8 years at two sites in Canterbury, New Zealand. N.Z. J. Agric. Res. 11: 829-47.

Martin, S.D. 1985: Pathogen tested potatoes in New Zealand. I. Production of pathogen tested seed. In: Hill, G.D.; Wratt, G.S. ed. Potato growing: a changing scene. Agronomy Society of New Zealand Special Publication No. 3: 35-38.

Miln, A.J. 1978: Potato aphids in the Manawatu. Proc. 31st N.Z. Weed and Pest Control Conf: : 79-84.

Nemecek, T.; Derron, J.O.; Fischlin, A.; Roth, O. 1995: Use of a crop-growth model coupled to an epidemic model to forecast yield and virus infection in seed potatoes. Chapter 18. In: Haverkort, A.J.; MacKerron D.K.L. ed. Potato Ecology and Modeling of Crops Under Conditions Limiting Growth. Netherlands, Kluwer Academic Publishing. Pp. 281-290. 
Pickup, J.; Brewer, A. 1994: The use of suction trap data in forecasting the incidence of potato leafroll virus in Scottish seed potatoes. Proc. Brighton Crop Protection Conf. - Pests and Diseases: 351-358.

Robert, Y.; Woodford, J.A.T.; Ducray-Bourdin, D.G. 2000: Some epidemiological approaches of aphid-borne virus diseases in seed potato crops in northern Europe. Virus Res. 71: 33-47.

Salazar, L.F. 1996: Potato viruses and their control. Peru, International Potato Centre.

Sigvald, K.R. 1998: Forecasting aphid-borne virus diseases. Chapter 13. In: Hadidi, A.; Khetarpal, R.K.; Koganezawa, H. ed. Plant Virus Disease Control. St Paul, Minnesota, APS Press.

Stufkens, M.A.W.; D.A.J. Teulon. 2001: Aphid species found in potato crops in Canterbury. N.Z. Plant Prot. 54: 235-239.

Stufkens, M.A.W.; Teulon, D.A.J.; Nicol, D.; Fletcher, J.D. 2000: Implications of aphid flight patterns for pest management of potatoes. N.Z. Plant Prot. 53: 78-82.

Teulon, D.A.J. 2001: Aphid/virus management. Grower 56 (2): 52-53.

Till, B.B. 1971: The effect of insecticides on the spread of potato leaf roll virus in seed potato fields at Pukekohe. N.Z. J. Agric. Res. 14: 458-468.

Thomas, P.E. 1983: Sources and dissemination of potato viruses in the Columbia Basin of the northwestern United States. Plant Disease 67: 744-747.

Thomas, P.E. 1997: Role of green peach aphid flights in the epidemiology of potato leaf roll disease in the Columbia Basin. Plant Disease 81: 1311-1316.

Wright, Q. 1997: Potato sector off to a good start. Commercial Grower 52(7): 19.

van Emden, H.F.; Eastop, V.F.; Hughes, R.D.; Way, M.J. 1969: The ecology of Myzus persicae. Ann. Rev. Entomol.14: 197-270. 